\title{
Komiteer for klinisk etikk - tid for endringer?
}

Alle helseforetak har i dag en komité som skal gi råd og veiledning til helsepersonell i saker der det er etiske utfordringer. Hensikten med opprettelsen av disse komiteene var å øke bevisstheten om de mange etiske utfordringene i klinisk medisin og gi lettere tilgang til kompetanse på området (1). I dette nummer av Tidsskriftet har Kalager og medarbeidere en tankevekkende artikkel med data fra klinikere som har brukt slike komiteer (2). De tar opp hvilke saker som ble drøftet og hvordan de ble behandlet.

Bare 20 komiteer av 37 oppga å ha videreformidlet spørreskjemaet, og kun 43 skjemaer $(50 \%)$ ble returnert. Det er derfor usikkert hvor representative svarene er. Likevel er det flere interessante funn. Omtrent halvparten av dem som kontaktet komiteene var leger, og de fleste pasientene kom fra psykiatriske avdelinger, medisinske/nevrologiske avdelinger og intensivavdelinger. Begrensning $\mathrm{i}$ behandling av alvorlig syk, pårørendes vilje og pasientautonomi var de vanligste temaene. Nytten av kontakten med og tilfredsheten med komiteene ble vurdert som ganske god. Studien dekket en periode på 18 måneder, og det lave antallet saker tyder på at klinisk etikk-komiteene brukes i svært liten utstrekning.

Det er mange og vanskelige etiske problemstillinger i klinisk medisin. Barn som rammes av sykdom og død, komplisert kreftbehandling, eksperimentell behandling, livsforlengende eller livsforkortende behandling, eutanasi, prioriteringer, samtykke og informasjon, organdonasjon, tvangstiltak, rusatferd, kollegiale utfordringer og konflikten mellom hensynet til pasientens behov og arbeidsgiverens rammevilkår - dette er bare noen av de krevende etiske spørsmålene man møter i de fleste større sykehus.

Man kunne nok ønske at den etiske bevissthet og kompetanse i de enkelte helseforetak var så god at det ikke var behov for noen etikkomité. Dette er imidlertid lite sannsynlig. Medisinen er i så rask utvikling at det ikke er mulig å få rutine på å takle stadig nye etiske problemstillinger. Dessuten er det lett å bli fanget i de rammer man er vant til å arbeide innenfor og ikke ha øye for andre perspektiver. I tillegg er det mange etiske dilemmaer som er så kompliserte at de aldri kan bli rutine. Opprettelsen av klinisk etikkkomiteer er derfor antakelig både riktig og viktig. Hva kan da være grunnen til at de blir så lite brukt?

En norsk studie har vist at mange leger synes slike komiteer kan være nyttige, men også truende - i en grad som kan minne om det å stå overfor en jury (3). I en annen studie oppga drøyt halvparten av legene at de hadde handlet mot sin samvittighet (4). Dette problemet er ikke minst aktuelt nå som kravet om effektivisering gjør seg stadig mer gjeldende. Å bruke mindre tid på hver pasient går ofte utover noe - grundigheten, muligheten til å informere og berolige. I mange tilfeller fører dette til at kvaliteten på arbeidet reduseres, ikke til at effektiviteten øker. Når man blir målt med effektivitetsmål som liggetid og antall pasientbehandlinger, øker sannsynligheten for faglige kompromisser - og dette kan gi mange etiske utfordringer. Av samme artikkel fremgår det også at nesten hver annen lege mente at arbeidsplassen manglet strategi for å takle etiske dilemmaer (4).

Det ganske store antallet tilknyttet den enkelte etikkomité og det begrensede antall saker kan tyde på at medlemmene får ganske liten erfaring. Når det deltar inntil 20 personer fra mange profesjoner, kan det stilles spørsmål ved hvor god kompetansen blir. Det er kanskje mer nærliggende å diskutere etiske problemstillinger med kolleger som i sin kliniske hverdag står overfor liknende utfordringer enn i en komité der medlemmene kan ha et helt annet erfaringsgrunnlag. Det er også et spørsmål om hvor grensen går mellom hva som er etikk, hva som er vanskelige faglige avgjørelser og hva som er konflikter i en arbeidssituasjon. Det er ikke opplagt hvorfor tiltak for å forbedre samarbeidet, som utgjorde $21 \%$ av sakene i undersøkelsen (2), hører hjemme i en komité for klinisk etikk.

I en studie i fire europeiske land, inklusive Norge, svarte $81 \%$ av legene at de ville finne det nyttig med tilgjengelig etisk kompetanse (5). Dette tyder på at behovet er ganske stort. Det gis mye undervisning i etikk, spesielt i lege- og sykepleierstudiene. Dette kan øke studentenes bevissthet om etiske problemer og om nødvendigheten av å utvikle sin etiske bevissthet etter ferdig utdanning. De legene som har hatt undervisning i medisinsk etikk under studiet, synes å være mest tilbøyelige til å benytte seg av tilgjengelig etisk kompetanse (5). Men selv om de som har hatt etikkundervisning er mer tilbøyelige til å søke råd når de er ferdige, unnlater det store flertallet å gjøre dette. Én mulig forklaring kan være at utdanningen er for teoretisk, slik at de allikevel ikke tenker på denne muligheten når de kommer opp i etiske dilemmaer.

Kalager og medarbeideres studie etterlater et inntrykk av at klinisk etikk-komiteene benyttes så lite at det er grunn til å foreta seg noe. Det mest nærliggende er vel å undersøke hvor stort behovet for å drøfte etiske problemstillinger er, særlig blant leger og sykepleiere. Hvis det er stort, bør det ses nærmere på hvordan frykten for å henvende seg til en slik komité kan reduseres. Muligens kan det være aktuelt for komiteene å gjøre seg mer kjent i de kliniske miljøene, i form av informasjon og ved å holde kurs. Ikke minst bør man undersøke hvilke erfaringer pasienter og pårørende har etter at deres saker har vært komitébehandlet. Kalager og medarbeidere viser at tilfredsheten blant dem som har kontaktet etikkomiteene er ganske høy. Det kan tyde på at det er mulig å utvikle disse komiteene slik at de får en viktig plass i klinisk medisin. Men betydelige begrensninger må overvinnes før dette potensialet blir fullt utviklet.

\section{Øivind Ekeberg}

oivind.ekeberg@uus.no

Øivind Ekeberg (f. 1945) er spesialist i psykiatri og dr.med. Han er overlege
i psykiatri ved Akuttmedisinsk avdeling, Oslo universitetssykehus, Ullevål,

Øivind Ekeberg (f. 1945) er spesialist i psykiatri og dr.med. Han er overlege
i psykiatri ved Akuttmedisinsk avdeling, Oslo universitetssykehus, Ullevål, og professor i medisinske atferdsfag ved Universitetet i Oslo.

\section{Oppgitte interessekonflikter: Ingen}

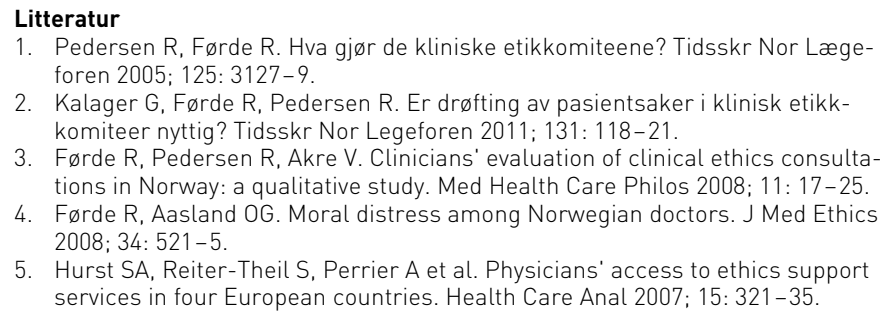

